7. Tychenko, L. (2013). May chords of Stryi. The din of freedom. 25 May. P. 3 [in Ukrainian].

8. Filonenko, L. (1993). Dedicated to Nestor Nyzhankivsky. Music. Vol. 14. P. 14 [in Ukrainian].

9. Chumak, O. (2003). Stryi waltz. The din of freedom. 27 May. P. 2 [in Ukrainian].

УДК $78.03+782.1$

DOI https://doi.org/10.31723/2524-0447-2020-31-2-19

Лариса Миколаӥвна Лобода

ORCID: 0000-0001-5446-2380

кандидат мистецтвознавства, доцент кафедри сольного співу

Одеської національної музичної академії імені А. В. Нежданової

loboda_l@i.ua

\title{
АКТУАЛЬНІ ПРИНЦИПИ ФОРМУВАННЯ ВОКАЛЬНОЇ ТЕХНІКИ ОПЕРНИХ СПІВАКІВ: МЕТОДИЧНИЙ АСПЕКТ
}

Метою статті є комплексне вивчення принципів формування вокальної техніки оперних співаків, що існують у різних вокально-педагогічних методиках. Вказаний напрямок дослідження дозволяє на підставі проведеного аналізу багатолітнього емпіричного досвіду вокалістів-практиків виявити систему універсальних настанов у процесі формування вокальних навичок. Методологічною основою статті $\epsilon$ системний підхід до вивчення вокальної техніки сучасних оперних співаків з включенням історичного, виконавського, методичного та емпіричного підходів. Наукова новизна статті полягає в тому, що в ній процес формування вокальної техніки отримує комплексне вивчення, що включає вивчення його $і$ як фізіологічного акту, $і$ як складного психологічного явища. Цілісне уявлення про необхідні складові частини сучасної вокальної техніки базуються на осмисленні єдності предметного змісту теоретичного, історичного, виконавського, методичного та художнього аспектів професійної діяльності вокаліста і визначення ї теоретико-методологічних основ. Висновки. Системне вивчення методичних принципів виховання вокалістів та аналіз вокальної техніки сучасних оперних співаків не тільки підтверджує, що володіння технікою

(С Лобода Л. М., 2020 
оперного співу є однією з основних вимог професії оперного артиста $i$ необхідною умовою, що забезпечує можливість реалізації оперним співаком своїх музично-художніх намірів, а й дозволяе визначити основні «складові» співочої техніки.

Вихідною точкою актуальної вокальної методики під час процесу роботи над технікою співу є опора на нові уявлення та засвоєння професійної парадигми мислення як комплексної системної програми, яка дозволяє створювати широкі можливості освоєння співочої професії. При цьому вже в процесі роботи над вокальною технікою співак отримує не тільки комплексні професійні знання стосовно функиіонування вокального апарату, а також і виконавські професійні навички для створення під час виконання відповідного та досконалого художнього образу.

Ключові слова: вокальне мистецтво, виконавська діяльність, постава голосу, творчий потенціал співака, вокальна методика, «прикриття звуку».

Loboda Larysa Mykolaivna, Ph.D. in History of Arts, Associate Professor at the Department of Solo Singing of the Odessa National A. V. Nezhdanova Academy of Music

Actual principles of formation of vocal technique of opera singers: methodical aspect

The aim of the article is a comprehensive study of the principles of formation of vocal technique of opera singers, existing in various vocal and pedagogical methods. The specified direction of research allows to reveal on the basis of the carried-out analysis of long-term empirical experience of vocalists-practitioners, system of universal attitudes in the course of formation of vocal skills. The methodological basis of the article is a systematic approach to the study of vocal technique of modern opera singers, with the inclusion of historical, executive, methodological and empirical approaches. The scientific novelty of the article is that in it the process of formation of vocal technique receives a comprehensive study, including the study of it as a physiological act and as a complex psychological phenomenon. A holistic view of the necessary components of modern vocal technique is based on understanding the unity of the subject content of the theoretical, historical, executive, methodological and artistic aspects of the vocalist's professional activity and determining its theoretical and methodological foundations. Conclusions. Systematic study of the existing methodological principles of vocal education and analysis of vocal technique of modern opera singers not only confirms that mastering the technique of opera singing is one of the main requirements of the opera profession and a necessary condition for the opera singer to realize his musical and artistic intentions. the main "components" of singing technique. The starting point of the current vocal technique in the process of working on the technique of singing is to rely on new ideas and mastering the professional paradigm of thinking as a comprehensive system program that allows you to create ample opportunities to learn the singing profession. At the same time, already in the process of working on vocal technique, the singer not only receives comprehensive professional knowledge about the functioning 
of the vocal apparatus, but also executive professional skills as a necessary component to create during the performance of the appropriate and perfect artistic image.

Key words: vocal art, performing activity, voice posture, creative potential of the singer, vocal technique, "hidden sound".

Актуальність. Виявлення та характеристика відмінностей у теоретичних настановах та педагогічних принципах вокальної підготовки співака є надзвичайно важливим та актуальним напрямом у системі сучасної музичної освіти. Зазначимо, що для успішного формування вокальних навичок та розвитку виконавських здібностей необхідним є комплексний підхід до цього складного завдання з боку педагога. Якщо співак-виконавець у своїй творчості керується сформованим в області суб'єктивних художніх уявлень суто індивідуальним за змістом творчим методом, демонструючи при цьому естетично переконливий художній результат, то це для нього можна вважати професійно і творчо цілком достатнім.

У процесі формування унікальної творчої індивідуальності виконавця та виконавських навичок вокаліста педагог повинен поєднувати різноманіття творчих та виховних завдань що стоять перед ним, як сутнісну підставу специфіки професії, а заняття з кожним конкретним студентом трактувати як важливий етап художньо-педагогічної творчості. У педагогічній практиці вокаліст повинен зосереджувати свою увагу не тільки на суто постановці голосового апарату студента, а ще й на розвитку його творчої індивідуальності, професійно й чітко оцінюючи цілісність унікальності його природнього творчого потенціалу, та адекватно визначаючи перспективи розвитку в професійному співочому оформленні. Роз'яснення даних методичних аспектів й основних принципів формування вокальної техніки оперних співаків $є$ надзвичайно актуальною та складною проблемою, що стоїть перед сучасним педагогом-вокалістом.

Загальний огляд літератури за темою. Серед багатьох праць, присвячених розгляду принципів формування вокальної техніки оперних співаків, треба виділити декілька груп досліджень. По-перше - це історичні огляди літератури про співоче мистецтво і наявні техніки співу оперних співаків (К. Мазурін, В. Багадуров, І. Назаренко, та ін.); по-друге, це роботи, присвячені виявленню природничим аспектам фонації у співі 
і осмисленню їх у художньо-педагогічній практиці (М. Гарcia, Д. Аспелунд, Л. Дмитрієв, Р. Юссон, та ін.); по-третє, це дослідження, спрямовані на вивчення специфічних методичних параметрів професійної співочої підготовки в класі сольного співу (Т. Глушакова, В. Крючков, М. Павлова, Л. Пашкіна, та ін.). При цьому ретроспектива досліджуваної нами проблеми може розглядатися у зв'язку з еволюцією самого мистецтва опери і з тими змінами в науці, якими визначалися спрямованість і можливості досліджень технічного аспекту співочого процесу.

Метою статті $\epsilon$ комплексне вивчення принципів формування вокальної техніки оперних співаків, що існують у різних вокально-педагогічних методиках. Вказаний напрямок дослідження дозволяє на підставі проведеного аналізу багатолітнього емпіричного досвіду вокалістів-практиків виявити систему універсальних настанов у процесі формування вокальних навичок. Методологічною основою статті $є$ системний підхід до вивчення вокальної техніки сучасних оперних співаків з включенням історичного, виконавського, методичного та емпіричного підходів. Наукова новизна статті полягає в тому, що в ній процес формування вокальної техніки отримує комплексне вивчення, що включає вивчення його і як фізіологічного акту, і як складного психологічного явища. Цілісне уявлення про необхідні складові частини сучасної вокальної техніки базуються на осмисленні єдності предметного змісту теоретичного, історичного, виконавського, методичного та художнього аспектів професійної діяльності вокаліста і визначенні її теоретико-методологічних основ.

Викладення основного матеріалу. У сучасному виконавському мистецтві галузь вокального виконавства демонструє нові форми й якості, а також значно розширила свій творчий діапазон, увібравши в себе різноманіття жанрово-стильових параметрів музики, видів й форм музичної діяльності. На сучасних музичних сценах гармонійно й плідно співіснують різні види музично-сценічних творів, серед яких провідне місце та найбільшу популярність отримують такі жанрові форми, як опера, мюзикл, оперета, музично-драматичний спектакль, а також різні види камерно-вокального виконавства. Кожен $з$ означених жанрових різновидів музичного мистецтва вимагає свого характерного вирішення у піднесенні вокального матеріалу. У зв'язку із цим велике значення у вокальному вико- 
навському мистецтві займає тенденція набуття виконавцями-вокалістами специфічних навичок, притаманних певній галузі мистецтва, у якій принципи вокального інтонування та самої постановки голосу мають характерні та специфічні риси. Окрім того, можна спостерігати виникнення двох окремих виконавських категорій співаків, серед яких перша виділяється посиленням суто вокально-співочого нахилу, у другій, більш універсальній, можна спостерігати вираження комплексного виконавського підходу, що включає в себе акторську майстерність, сценічний рух. Слід зазначити, що саме другий варіант сьогодні $є$ найбільш затребуваним та актуальним, адже за допомогою нього можливо більш повно розкривати художньо-образну сферу твору, який виконує вокаліст.

Під час розгляду вокально-педагогічного процесу як системи методичних та художньо-виконавських настанов відкривається можливість простеження та усвідомлення шляху професійного становлення співака та розкриттю його творчого потенціалу. У даному підході виокремлюються декілька надзвичайно важливих проблем, які мають провідне значення у виявленні всіх аспектів професійного формування вокаліста, серед яких провідне значення мають проблеми інтонування та принципи вокального тембрового вираження художнього образу.

Серед багатьох музикознавчих та мистецтвознавчих робіт, у тому числі у роботах видатного педагога та театрознавця А. Авдєєва, існує думка про те, що якщо специфічною особливістю мистецтва в цілому є образне відображення дійсності, то очевидно, що специфічною особливістю кожного 3 видів мистецтва, окремо взятого, буде особливий спосіб, особлива форма образного відображення. Інакше кажучи, найбільш важливим та у багатьох випадках визначальним фактором стає те, яким способом у даному конкретному виді мистецтва образне відображення дійсності здійснюється та яким чином та за допомогою яких виконавських прийомів відбувається втілення художнього образу [1].

Для співака-вокаліста головним «інструментом» у створенні художнього образу стає сам голос, і всі виконавчі завдання грунтуються на поєднанні голосових можливостей та вмінь, серед яких провідними є розкриття тембру, яскравість та гнучкість, діапазон, вміння користуватися музичними штрихами й динамічними відтінками у створенні художнього образу. Тому поруч із надзвичайним значенням особистіс- 
ного обдарування та природніми вокальними даними співака велике значення має досконалість виконавських навичок безпосередньо у володінні голосом, загальне артистичне обдарування та акторські якості.

Отже, сучасний еталон професійного вокального співу передбачає володіння як технікою вокалу, так і його виразними якостями, тому методичний арсенал вокального педагога повинен відповідати високим стандартам й вибудовуватися щодо цілей і завдань конкретного виду музично-сценічної діяльності. Художньо-емпіричний спосіб є сутнісною основою передачі професійно значимої інформації школи співу від учителя учню.

За своєю суттю школа є не лише носієм головного змісту вокально-виконавської естетики й способів досягнення в співі цілісності єднання професійної майстерності й досконалої майстерності у створенні художнього образу під час виконання, а й методологічні засади, які забезпечують спадкоємність в мистецтві співу та вокальній педагогіці.

Відомий фізіолог, дослідник співочого голосу Р. Юссон визначає метод виховання співочого голосу як «сукупність систематизованих вказівок і порад, поступове засвоєння яких призводить до появи у будь-якої здорового людини певних співочих навичок або вокальної техніки, що забезпечує бажані діапазон, силу і тембр голосу при нестомлюваності голосового апарату» [7, с. 178].

У вокальній педагогіці також існує таке поняття, як м'язовий прийом - спосіб прямого свідомого впливу на роботу окремих частин голосового апарату, що дозволяє значною мірою коригувати якість звучання голосу учня. Велике значення таких прийомів у вокальному навчанні надавав Л. Дмитрієв, який вважав, що кожен педагог повинен володіти комплексом різноманітних м'язових прийомів, чітко уявляти їх дію на рівні фізіології, та принципи їх застосування у різних виконавських ситуаціях [5].

Як відомо, головна проблема навчання вокальній техніці оперного співу полягає в тому, що в більшості випадків діапазон грудного звучання співочого голосу у початківців співаків не перевищує одного-півтора октав. Саме цей фактор зумовлює головне завдання, що стоїть перед педагогом-вокалістом - навчання та практичне засвоєння технічних навичок молодим виконавцем-вокалістом, за допомогою володіння 
якими зберігається грудне звучання голосу в більш високій теситурі, і тим самим розширюється діапазон майбутнього виконавця, що є необхідною умовою для його подальшої професійної діяльності.

У вокальній теорії ці навички пов'язані з поняттям «прикриття звуку», дефініції, що увійшла у методичну вокальну літературу на рубежі XIX-XX століть. Треба зауважити, що хоча загальноприйнятим $є$ розуміння практичної сторони даної категорії, разом із тим до сьогодення поняття «прикриття звуку» застосовується досить активно, але остаточного його визначення до теперішнього часу не було здійснено. Ще порівняно недавно в методичній літературі домінувало переконання, що прийом прикриття використовується тільки чоловіками у верхній частині діапазону їхніх голосів [4]. Із плином часу у вокальній педагогіці розповсюджувались уявлення про зниження кордону прикриття звуку, і сьогодні у більшості методичних праць ХХ ст., присвячених даній проблемі, все більшого визнання знаходить думка, що голос оперного співака повинен бути прикритий на всьому діапазоні (даної позиції дотримуються Д. Аспелунд, Л. Дмитрієв, Р. Юссон, В. Юшманов, й баг. ін. [3; 5; 7; 8]).

Відмітимо, що теоретична та процесуально-технічна складова частина цього прийому у багатьох методичних працях пояснюється зовсім по-різному. Так, наприклад, якщо в роботах Р. Юссона механізм прикриття звуку пов'язується з опусканням гортані і розширенням нижньої частини глотки при переході до верхньої частини діапазону голосу, то, на думку Л. Дмитрієва, прийом «прикриття звуку» включає в себе особливий змішаний режим роботи голосових складок з одночасним затемненням звуку. У повсякденній практиці вокалісти, як правило, намагаються досягати ефекту «прикриття» шляхом округлення голосних та роботою з головними резонаторами, в яких повинен надсилатися звук.

Треба відмітити, що хоча в більшості вокальних методичних праць виражені унікальні підходи, апробовані у власній педагогічній практиці автора методики, більшість дослідників сходяться в думці стосовно складної проблеми «прикриття звуку», що механізм прикриття звуку спрямований на створення підвищеного акустичного опору в ротоглотці і верхніх дихальних шляхах. Поруч із цим у безпосередньому практичному застосуванні даної концепції виникає проблема відсут- 
ності чіткого розуміння, в чому реально полягає прикриття звуку, що призводить до використання даної методики в кожному окремому випадку емпірично знайденим способом підлаштовуючись під індивідуальні характерні особливості та здібності співака. Тому існують деякі вокальні методики (наприклад, у більшості болгарських шкіл, в яких педагоги відмовлялися від використання поняття «прикриття звуку»).

Як і в будь-якому виді мистецтва, сама по собі техніка володіння голосом як особливим інструментом ще не є художньою творчістю і для виникнення художньо досконалої інтерпретації повинні бути виконані ще багато завдань. Головним аспектом вокально-технічної роботи співака є створення умов та забезпечення фізичної можливості для виникнення художньої складової виконання, а також підтримка психофізичної готовності і здатності організму вокаліста до практичної pеалізації художніх намірів під час творчої діяльності.

Необхідність спеціальної роботи над психофізичною складовою частиною співочого процесу для збереження необхідного для співочої роботи фізичного функціонального стану свого організму супроводжує співака протягом усього його творчого життя. Про це вельми виразно говорить Л. Дмитрієв, який обговорював цю проблему з багатьма видатними співаками Ла Скала: «Співак в Італії удосконалює голос протягом всієї своєї співочої діяльності. Усі співаки щодня шліфують свою техніку на вправах і вокалізах. Кількість часу, яку вони витрачають в день на роботу з удосконалення техніки, є різною, але сам факт щоденного, систематичного технічного тренажу $€$ незаперечним. Власне, факт обов'язковості такого тренажу протягом усього життя не є новиною ... Наші інтерв'ю лише підтверджують існування принципу постійного вокально-технічного вдосконалення і на сучасному етапі розвитку італійської школи співу. Цей постійний вокальний чисто технічний тренаж, робота над вокальним звуком дозволяють італійським співакам підтримувати високий еталон правильного академічного звучання голосу і якісно співати до старості» [6, с. 157].

У зв'язку із цим не можна не відзначити, що вокально-технічна робота для професійного співака виявляється засобом, що дозволяє благополучно переживати періоди емоційного спаду, і нерідко - ефективним способом приведення свого організму в необхідний для співу стан. Разом із тим використання конкретних м'язових прийомів в досягненні ідеалу 
звучання вимагає від педагога ясного розуміння загальної природи голосу студента-вокаліста і ретельного контролю над правильністю виконання вправ, адже існує розповсюджена думка про те, що «хто не володіє прийомом, не повинен і навчати йому» [2, с. 7]. Важливим аспектом у формуванні вокальних навичок та роботі над виконавськими прийомами стає чуйне ставлення до голосового апарату, з урахуванням його індивідуальних особливостей, адже неуважне ставлення до цього приводить до важких наслідків, що може стати перешкодою для подальшої професійної діяльності студента.

Водночас для успішного розвитку співочих навичок у більшості наявних вокальних методиках пропонуються використовування всіх можливих шляхів, методів й прийомів, що допомагають їх формуванню. Л. Дмитрієв [5] вважає, що доцільний підбір вокально-педагогічного матеріалу і відповідних до нього найбільш корисних фонетичних вправ, показ голосом як реалізація безпосереднього контакту між педагогом та учнем, детальний показ необхідних м'язових рухів, словесні пояснення - все це створює обов'язковий комплекс прийомів та дій на шляху розвитку голосу та формування вокальних навичок.

Ефективність використання асоціацій у навчанні вокальній техніці давно відома і співакам, і дослідникам вокального мистецтва. Разом із тим цей феномен залишається загадкою, і за відсутністю іншого пояснення найбільш часто можна почути думку, що використання асоціацій є маневром, що дозволяє педагогу активізувати емоційну сферу учня і відвернути його увагу від м'язових затискачів, що з'являються в його тілі.

При тому, що дія асоціацій направлена на уяву студента, справа не в емоціях або фантазіях, що відволікають увагу співаючого. Причина пріоритетного використання асоціацій під час навчання вокальній техніці полягає перш за все в тому, що вони насправді $є$ універсальним засобом корекції енергетики фонаційного процесу, що дозволяє співає використовувати регуляторні можливості підсвідомості і звести до мінімуму своє вольове втручання в роботу голосоутворюючих органів співочого інструменту.

Асоціація дає підсвідомості цілісне уявлення про всю сукупність умов роботи тієї чи іншої частини співочого інструменту та відкриває для співака можливість усвідомленого використання всього минулого досвіду підсвідомості, що 
включає не тільки фізичний досвід тіла, а й інтелектуальне знання, про що вказує С. Осадча [9]. Асоціації дозволяють співаку зберігати інтелектуально-вольовий контроль за фонаційним процесом і коригувати роботу підсвідомості, не заважаючи, а в необхідних випадках і допомагаючи йому.

Знаходячи нові асоціації і уточнюючи вже відомі, педагог може досить тонко коригувати умови фонаційного процесу, а у співака з'являється можливість відтворення цих умов у самостійній роботі. Важливим є і та обставина, що несподівані і яскраві асоціації, які збуджують уяву, роблять знайомство зі своїм голосом і вокально-технічну роботу цікавими для співаючого. Освоєння вокальної техніки повинно бути для співака активним процесом творення, а не боротьбою з помилками, недоліками або затискачами. Для того, хто навчається, це повинен бути позитивний процес знайомства зі своїм голосом, його можливостями, а також різними фазами його активної функціональної розробки.

Висновки. Системне вивчення наявних методичних принципів виховання вокалістів та аналіз вокальної техніки сучасних оперних співаків не тільки підтверджує, що володіння технікою оперного співу є однією з основних вимог професії оперного артиста і необхідною умовою, що забезпечує можливість реалізації оперним співаком своїх музично-художніх намірів, а й дозволяє визначити основні «складові» співочої техніки.

Вихідною точкою актуальної вокальної методики під час процесу роботи над технікою співу є опора на нові уявлення та засвоєння професійної парадигми мислення як комплексної системної програми, яка дозволяє створювати широкі можливості освоєння співочої професії. При цьому вже в процесі роботи над вокальною технікою співак \отримує комплексні професійні знання стосовно функціонування вокального апарату, виконавські професійні навички як необхідну складову частину для створення під час виконання відповідного та досконалого художнього образу.

Якісно нові перспективи відкриває нова парадигма мислення і для теорії співочого і оперного мистецтва. Про необхідність створення актуальної теорії співочого мистецтва і професії оперного артиста, яка забезпечувала б практикам можливість орієнтуватися в професії, допомагала знаходити свої шляхи і способи вирішення виникаючих проблем, з рівною мірою розуміння використовуючи при цьому емпіричні 
знахідки своїх попередників і сучасну наукову інформацію, вже давно говорилося. Разом із тим тільки наприкінці XX століття стало очевидним, що для створення такої теорії потрібно знаходження і розробка принципово нової парадигми мислення, що грунтується на достовірному знанні природи і життєвого призначення самого феномена співочого мистецтва і ширше - феномена художньої творчості.

\section{СПИСОК ЛІТЕРАТУРИ}

1. Авдеев А. Происхождение театра. Ленинград-Москав : Искусство, 1959. 268 с.

2. Ангуладзе Н. Ноmo cantor: Очерки вокального искусства. Москва : «Аграф», 2003. 240 с.

3. Аспелунд Д. Развитие певца и его голоса. Москва-Ленинград : Музгиз, 1952. 190 с.

4. Багадуров В. Очерки по истории вокальной педагогики. Москва : Гос. муз. изд., 1956. 267 с.

5. Дмитриев Л. Основы вокальной методики. Москва : Музыка, 2007. $368 \mathrm{c}$.

6. Дмитриев Л. Солисты театра Ла Скала о вокальном искусстве. Москва : 2002. 184 с.

7. Юссон Р. Певческий голос. Москва : Музыка, 1974. 264 с.

8. Юшманов В. Вокальная техника и ее парадоксы. Монография. Санкт-Петербург : Деан, 2001. 128 с.

9. Osadcha S. Semiological aspect of studying the structure and chronotopic features of the orthodox liturgical text. Music semiology: categories and methods: collective monograph. Lviv-Toruń: Liha-Pres, 2020. C. $20-36$.

\section{REFERENCES}

1. Avdeev, A. (1959) The origin of the theater. L.-M. Art. [in Russian]

2. Anguladze, N. (2003) Homo cantor: Essays on vocal art. Moscow: «Agraf». [in Russian]

3. Aspelund, D. (1952) Development of the singer and his voice. M-L.: Muzgiz. [in Russian]

4. Bagadurov, V. (1956) Essays on the history of vocal pedagogy. Moscow: State. muses. ed. [in Russian]

5. Dmitriev, L. (2007) Fundamentals of vocal techniques. Moscow: Muzyka. [in Russian]

6. Dmitriev, L. (2002) Soloists of the Teatro alla Scala on vocal art. Moscow. [in Russian]

7. Yusson, R. (1974) Singing voice. Moscow: Muzyka. [in Russian]

8. Yushmanov, V. (2001) Vocal technique and its paradoxes. Monograph. SPb.: Dean. [in Russian]

9. Osadcha, S. (2020) Semiological aspect of studying the structure and chronotopic features of the orthodox liturgical text. Music semiology: categories and methods: collective monograph. Lviv-Torun: Liha-Pres. [in English]. 